Helena Teiriä $M D, *$

Arvi Yli-Hankala MD PhD, ${ }^{\dagger}$

Pertti J. Neuvonen MD PhD, ${ }^{\ddagger}$

Klaus T. Olkkola MD PhD*

\title{
Cigarette smoking does not affect thiopentone pharmacodynamic or pharmacokinetic behaviour
}

\begin{abstract}
Purpose: Smoking affects the pharmacodynamic and pharmacokinetic behaviour of several drugs. In smokers, induction of anaesthesia is often stormy. In this study we have determined whether cigarette smoking affected thiopentone pharmacodynamic or pharmacokinetic behaviour during induction of anaesthesia.

Methods: Ffteen smokers and 15 non-smokers, scheduled for elective surgery, were studied. Heart rate, invasive arterial pressures and middle latency auditory evoked potentials were recorded awake and during thiopentone induction ( $9 \mathrm{mg} \mathrm{kg}^{-}$lean body mass), before and after tracheal intubation. Blood was sampled up to $24 \mathrm{hr}$ after induction to measure thiopentone plasma concentrations and to calculate pharmacokinetic parameters.
\end{abstract}

Results: Anaesthesia was adequate in all patients, although haemodynamic intubation response was not blunted. Latencies or amplitudes of middle latency auditory evoked potentials (MLAEP) did not differ between the groups. The postintubation latencies of $\mathrm{Nb}$ waves were $48.9 \pm 8.1 \mathrm{msec}$ (mean $\pm \mathrm{SD}$ ) in smokers and $48.1 \pm 8.5 \mathrm{msec}$ in nonsmokers. Pharmacokinetic data showed no differences between smokers and non-smokers. Clearance of thiopentone was $2.9 \pm 1.1 \mathrm{ml} \cdot \mathrm{min}^{-1} \cdot \mathrm{kg}^{-1}$ in smokers and $3.3 \pm 1.0 \mathrm{ml} \cdot \mathrm{min}^{-1} \cdot \mathrm{kg}^{-1}$ in non-smokers and elimination haff life of thiopentone was $12.5 \pm 6.3 \mathrm{hr}$ in smokers and $10.7 \pm 3.1 \mathrm{hr}$ in non-smokers, respectively. The haemodynamic response after the induction dose of thiopentone and after tracheal intubation were similar in smokers and non-smokers. Mean postintubation systolic arterial pressures were $192 \pm 35 \mathrm{vs} 189 \pm 20 \mathrm{mmHg}$ and mean postintubation heart rates were $103 \pm 12$ vs $102 \pm 17$ beat per minute (bpm) in smokers and non-smokers, respectively.

Conclusion: We conclude, that cigarette smoking does not affect the pharmacodynamic or pharmacokinetic behaviour of thiopentone.

Objectif : Le tabagisme influence le comportement pharmacodynamique et pharmacocinétique de plusieurs produits. Chez le fumeur, l'induction de l'anesthésie est souvent mouvementée. Cette étude visait à déterminer si la cigarette affectait le comportement phamacodynamique et pharmacocinétique du thiopental pendant l'induction de l'anesthésie.

Méthodes : Quinze fumeurs et 15 non fumeurs programmés pour une intervention non urgente participaient à l'etude. La fréquence cardiaque, la pression artérielle sanglante et les potentiels auditifs de latence moyenne ont été enregistrés à l'état vigile et pendant linduction de l'anesthésie au thiopental ( $9 \mathrm{mg} \cdot \mathrm{kg}^{\prime}$ de poids maigre), avant et après l'intubation de la trachée. Du sang a été prélevé dans les $24 \mathrm{~h}$ suivant l'induction pour le dosage plasmatique du thiopental et le calcul des paramètres pharmacocinétiques.

Résultats : Tous les patients ont reçu une anesthésie satisfaisante mais sans qu'il y ait eu abolition de la réponse hémodynamique àl l'intubation. Les latences ou amplitudes des potentiels évoqués auditifs de latence moyenne (MLAEP) ne différaient pas entre les groupes. Après l'intubation, la latence des ondes Nb était 48.9 $\pm 8.1 \mathrm{~ms}$ (moyenne \pm ÉT) chez le fumeurs et $48,1 \pm 8,5 \mathrm{~ms}$ chez les non fumeurs. La clairance du thiopental était de $2,9 \pm 1,1 \mathrm{ml} \cdot \mathrm{min}^{-1} \cdot \mathrm{kg}^{-1}$ chez les fumeurs et de $3,3 \pm 1,0 \mathrm{ml} \cdot \mathrm{min}^{-1} \cdot \mathrm{kg}^{-1}$ chez les non fumeurs ; la demi-vie d'élimination du thiopental était de $12,5 \pm 6,3$ chez les fumeurs et de $10,7 \pm 3,1$ chez les non fumeurs. La réponse hémodynamique après la dose d'induction de thiopental et après l'intubation ne différait pas entre les deux groupes. Après l'intubation, la pression artérielle systolique respective des fumeurs et des non fumeurs était $192 \pm 53 \mathrm{vs} 189 \pm 20 \mathrm{mmHg}$ et la fréquence cardiaque moyenne respective postintubation était $103 \pm 12$ v $102 \pm 17$ bpm.

Conclusion : La cigarette n'a pas d'influence sur le comportement pharmacodynamique et pharmacocinétique du thiopental.

From the Department of Anaesthesia, * Helsinki University Central Hospital, Helsinki, Finland, Anaesthesia Research Group, Department of Obstetrics and Gynaecology, ${ }^{\dagger}$ Helsinki University Central Hospital, Helsinki, Finland and Department of Clinical Pharmacology, ${ }^{\ddagger}$ University of Helsinki, Helsinki, Finland.

Address correspondense to: Dr. Helena Teiriä, Womens Hospital, Department of Anaesthesia, Helsinki University Central Hospital, Haartmaninkatu 2, FIN-00290 Helsinki, Finland; Fax: 358-9-4714803; E-mail: helena.puroohuch. $f$

Accepted for publication September 11, 1997. 


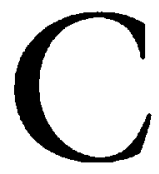

IGARETTE smoking alters the pharmacodynamic $^{1,2}$ or pharmacokinetic ${ }^{1-4}$ behaviour of many drugs. For example, smokers receiving benzodiazepines appear to be more resistant to their sedative effects than are non-smokers. This reduced drowsiness may be due to diminished endorgan responsiveness in smokers. ${ }^{5}$ Smoking is known to induce drug metabolising enzymes, especially in the liver. ${ }^{1-4}$ Thus, the metabolism of hepatically eliminated drugs, like thiopentone, might be modified by cigarette smoking. Smoking is a predisposing factor to coughing, mucous hypersecretion, breath holding and laryngospasm during anaesthesia. ${ }^{6}$ It has been suggested, that these symptoms are due to increased airway reflex sensitivity, ${ }^{7}$ but they may also be caused by inadequate levels of anaesthesia in smokers.

Altered drug response cannot always be explained by variable pharmacokinetic behaviour. Thiopentone is a commonly used intravenous hypnotic with a wide interindividual variation in dose requirement. ${ }^{8,9}$ The effect of tobacco smoking on the pharmacodynamics of thiopentone is not clear. Objective measures have not been used to compare the pharmacodynamic potency of thiopentone between smoking and non-smoking patients. Therefore, we studied the pharmacodynamic and pharmacokinetic behaviour of thiopentone in smokers and non-smokers in a clinical setting. We hypothesised that smokers were more resistant to the effects of thiopentone than non-smokers.

\section{Methods}

Based on our own unpublished data, the mean $\mathrm{Nb}$ wave latency of auditory evoked potential after thiopentone induction and tracheal intubation is $49 \mathrm{msec}$, with standard deviation around $8.5 \mathrm{msec}$. It was calculated, that 15 patients were needed in each group to demonstrate a $20 \%$ latency difference at a level of significance of $P<0.05$ and power of $85 \%$. These 30 subjects would have $85 \%$ power to show $16 \%$ difference in the clearance of thiopentone. ${ }^{10}$ We obtained institutional approval and written informed consent to study 15 smokers and 15 non-smokers, all ASA I, scheduled for elective general or urological surgery (Table I). Smokers inhaled $>15$ cigarettes daily. Patients who were receiving regular medication, had a body mass index ${ }^{11}$ $>27$, were $>50$-yr-old or who consumed $>20$ units alcohol (one unit $=\mathrm{a}$ glass of wine, $\mathrm{a}$ bottle of beer or one drink) per week were excluded from the study.

In all patients the radial artery was cannulated under local anaesthesia for invasive blood pressure monitoring and a large cubital vein was cannulated for intravenous infusion. A Neuropack Four mini (Nihon Kohden Ltd; Japan) evoked potential device was used for acoustic stimulation and recording of evoked potentials. Clicks
TABLE I Demographic data (mean $\pm S D)$.

\begin{tabular}{lll}
\hline & Smokers & Non-smokers \\
\hline $\mathrm{n}$ & 15 & 15 \\
Sex $(\mathrm{M} / \mathrm{F})$ & $9 / 6$ & $10 / 5$ \\
Age $(\mathrm{yr})$ & $37 \pm 10$ & $40 \pm 10$ \\
Weight $(\mathrm{kg})$ & $72 \pm 7$ & $72 \pm 11$ \\
Height $(\mathrm{cm})$ & $174 \pm 7$ & $173 \pm 8$ \\
LBM $(\mathrm{kg})$ & $54.7 \pm 5.1$ & $53.8 \pm 6.8$ \\
Thiopentone dose $(\mathrm{mg})$ & $507 \pm 43$ & $500 \pm 62$ \\
\hline
\end{tabular}

of $85 \mathrm{~dB}$ above normal hearing level were presented to the patients binaurally via headphones at a rate of 9.0 $\mathrm{Hz}$. Recording electrodes were positioned at the forehead and at the right mastoid. Inter-electrode impedances were maintained $<5.0 \mathrm{k} \Omega$. In each recording, 500 clicks of $0.1 \mathrm{msec}$ were averaged using $20-1000 \mathrm{~Hz}$ bandpass, 8-bit resolution, A/D conversion time of 10 msec and epoch time of $100 \mathrm{msec}$. Artifacts were detected automatically and rejected. The typical time required to acquire a waveform was $60 \mathrm{sec}$. Latencies and amplitudes were measured manually on the screen of the evoked potential device. Vertical and horizontal cursors were used. In amplitude measuring, $\mathrm{Na}$-Pa difference, (i.e., $\mathrm{Pa}$ amplitude), as well as $\mathrm{Pa}-\mathrm{Nb}$ difference ( $\mathrm{Nb}$ amplitude) were calculated. All latencies and amplitudes were analysed blinded by one of the authors (HT) (Figure 1).

Anaesthesia was induced with thiopentone $9 \mathrm{mg} \cdot \mathrm{kg}^{-1}$ lean body mass (LBM). ${ }^{12}$ This is equal to

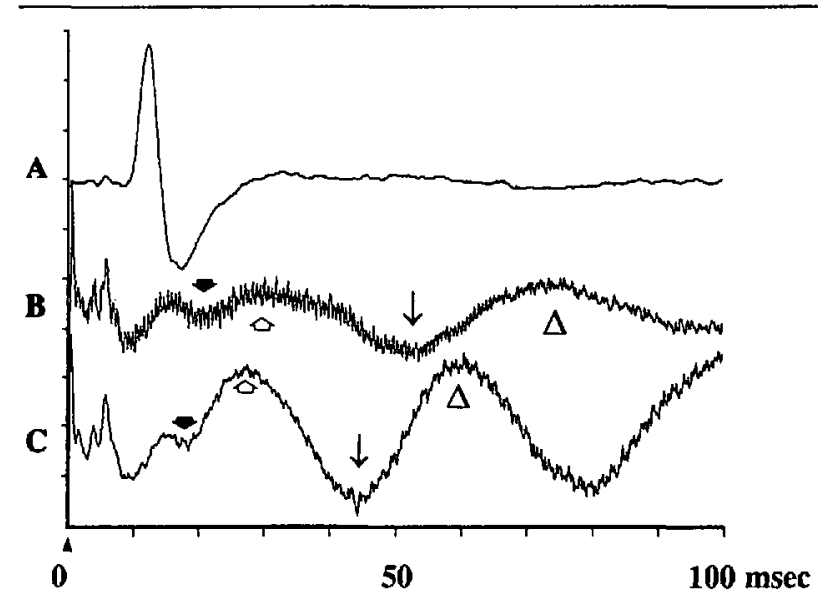

FIGURE 1 Auditory evoked potential registrations in one patient. $\mathrm{A}=$ averaged response awake (amplitude $5 \mu \mathrm{V} \cdot \mathrm{div}^{-1}$ ). $\mathrm{B}=$ response after thiopentone induction $\left(0.62 \mu \mathrm{V} \cdot \mathrm{div}^{-1}\right) . \mathrm{C}=$ response after tracheal intubation $\left(0.62 \mu \mathrm{V} \cdot \mathrm{div}^{-1}\right)$. Binaural stimulus was presented at 0 , and each response was averaged up to $100 \mathrm{msec}$.

$-, \diamond, \downarrow$ and $\Delta$ indicate $\mathrm{Na}, \mathrm{Pa}, \mathrm{Nb}$ and $\mathrm{Pb}$ waveforms, respectively. 
approximately $7 \mathrm{mg} \cdot \mathrm{kg}^{-1}$ body weight in normal person. Thiopentone was given at a rate of $10 \mathrm{mg} \cdot \mathrm{sec}^{-1}$. Vecuronium, $0.1 \mathrm{mg} \cdot \mathrm{kg}^{-1}$, was given to facilitate tracheal intubation. The lungs were ventilated with oxygen $100 \%$ and the trachea was intubated 2.5 min after the thiopentone injection. Arterial pressures, heart rate and middle latency auditory evoked potentials (MLAEP) were recorded awake, immediately following the thiopentone injection and three minutes after thiopentone. After this, anaesthesia was continued according to the clinical needs.

Arterial blood samples were drawn into EDTA tubes immediately before administration of thiopentone and $2,5,15,30,45$ and $60 \mathrm{~min}$ and 2,4 and $6 \mathrm{hr}$ after thiopentone. After this, venous blood samples were drawn at 12 and $24 \mathrm{hr}$ after administration of thiopentone. Plasma was separated within $60 \mathrm{~min}$ and stored at $-40^{\circ} \mathrm{C}$ until thiopentone concentrations were determined by high-performance liquid chromatography. ${ }^{13}$ The detection limit of the assay was $0.2 \mu \mathrm{g} \cdot \mathrm{ml}^{-1}$. The coefficient of variation at $3.1 \mu \mathrm{gg} \cdot \mathrm{ml}^{-1}$ was $4.4 \%(\mathrm{n}=13)$ and at $35.9 \mu \mathrm{g} \cdot \mathrm{ml}^{-1} \mathbf{5 . 2} \%(\mathrm{n}=13)$. All patients were interviewed $24 \mathrm{hr}$ after anaesthesia for memories associated with events occurring during anaesthetic induction.

The individual plasma concentrations were fitted to the following multiexponential function with the aid of a microcomputer-based nonlinear regression programme using iteratively reweighted least squares with reciprocal squared prediction weighting ${ }^{14}$

$$
\dot{C}_{p}(t)=\sum_{i=1}^{n} A_{i} e^{-a_{i} t}
$$

where $\mathrm{Cp}(\mathrm{t})$ is the plasma concentration of thiopentone at time $t, A_{i}$ is a zero-time intercept, and $a_{i}$ is a disposition rate constant. The goodness of the fit was determined by Akaike's information criterion ${ }^{15}$ and by assessment of randomness of "scatter" of actual data points about the fitted function. The initial estimates were obtained using an iterative curve stripping technique. ${ }^{16}$ The pharmacokinetic parameters, "fast"and "slow" half-lives $\left(T^{1 / 2}, 1\right.$ and $\left.T^{1 / 2}, 2\right)$, volume of central compartment $\left(\mathrm{V}_{\mathrm{c}}\right)$, steady-state volume of distribution $\left(V_{s s}\right)$ and clearance (CL) were calculated according to standard formulae. ${ }^{17} \mathrm{~A}$ correction was made for the infusion time. ${ }^{18}$

Pharmacokinetic parameters were compared with Student's $t$ test. Two way ANOVA for repeated measurements, followed by post-hoc $t$ tests were used for the statistical testing of pharmacodynamic parameters. Factors in ANOVA were smoking status and time; tests were repeated in three levels: preinduction, preintubation and postintubation. $P<0.05$ was considered to indicate statistically significant differences.

\section{Results}

Except for smoking, the social habits did not differ: alcohol, coffee and tea consumption were moderate and at the same level in both groups. The induction of anaesthesia was accomplished smoothly in all patients. No patient had $\mathrm{SpO}_{2}<97 \%$ and no patient moved or coughed during laryngoscopy and intubation. Anaesthesia was adequate in all patients, without recall of intraoperative events.

Thiopentone caused increases in the latencies of auditory evoked waveforms $\mathrm{Na}, \mathrm{Pa}$ and $\mathrm{Nb}$, and decreases in the amplitudes of $\mathrm{Pa}$ and $\mathrm{Nb}$ waveforms in both groups, compared with the pre-induction values (Table II). After tracheal intubation the latencies of auditory evoked waveforms $\mathrm{Na}, \mathrm{Pa}$ and $\mathrm{Nb}$ shortened again in both smokers and non-smokers, compared with the pre-intubation values (Table II). No differences were seen between the smokers and non-smokers.

The decay of the thiopentone plasma concentrations could be described adequately with a biexponential function in all cases (Figure 2). The pharmacokinetic

TABLE II Auditory evoked potential data.

\begin{tabular}{lllll}
\hline & & Preinduction & Preintubation & Postintubation \\
\hline $\mathrm{L}-\mathrm{Na}$ & $\mathrm{S}$ & $16.4 \pm 1.8$ & $24.2 \pm 6.5^{*}$ & $19.9 \pm 3.5^{\dagger}$ \\
$(\mathrm{msec})$ & $\mathrm{NS}$ & $15.8 \pm 1.9$ & $25.7 \pm 6.7^{\star}$ & $21.8 \pm 5.4^{\star}$ \\
$\mathrm{L}-\mathrm{Pa}$ & $\mathrm{S}$ & $26.6 \pm 5.2$ & $41.1 \pm 10.3^{\star}$ & $33.7 \pm 6.7^{\dagger}$ \\
$(\mathrm{msec})$ & $\mathrm{NS}$ & $26.6 \pm 5.9$ & $39.6 \pm 10.1^{\star}$ & $32.5 \pm 6.7^{\dagger}$ \\
$\mathrm{L}-\mathrm{Nb}$ & $\mathrm{S}$ & $33.7 \pm 5.4$ & $59.2 \pm 12.7^{\star}$ & $48.9 \pm 8.1^{\dagger}$ \\
$(\mathrm{msec})$ & $\mathrm{NS}$ & $34.5 \pm 8.0$ & $60.6 \pm 13.1^{*}$ & $48.1 \pm 8.5^{\dagger}$ \\
$\mathrm{A}-\mathrm{Pa}$ & $\mathrm{S}$ & $5.7 \pm 4.3$ & $1.0 \pm 1.5^{\star}$ & $0.8 \pm 0.3$ \\
$(\mu \mathrm{V})$ & $\mathrm{NS}$ & $6.6 \pm 4.7$ & $0.5 \pm 0.3^{*}$ & $0.8 \pm 0.4^{\dagger}$ \\
$\mathrm{A}-\mathrm{Nb}$ & $\mathrm{S}$ & $1.5 \pm 1.1$ & $0.7 \pm 1.1^{\star}$ & $0.8 \pm 0.4$ \\
$(\mu \mathrm{V})$ & $\mathrm{NS}$ & $1.5 \pm 1.8$ & $0.6 \pm 0.3$ & $0.8 \pm 0.6$ \\
\hline
\end{tabular}

mean $\pm \mathrm{SD} ; \mathrm{S}=$ smokers, $\mathrm{NS}=$ non-smokers; $\mathrm{L}-\mathrm{Na}=$ latency of $\mathrm{Na}$ wave, $\mathrm{L}-\mathrm{Pa}=$ latency of $\mathrm{Pa}$ wave, $\mathrm{L}-\mathrm{Nb}=$ latency of $\mathrm{Nb}$ wave; $\mathrm{A}-\mathrm{Pa}=$ voltage difference between $\mathrm{Na}$ and $\mathrm{Pa}$ wives, $\mathrm{A}-\mathrm{Nb}=$ voltage difference between $\mathrm{Pa}$ and $\mathrm{Nb}$ waves; Significance from preinduction values: $P<0.05^{\star}$ within the groups; Significance from preintubation values: $P<0.05^{\dagger}$ within the groups.

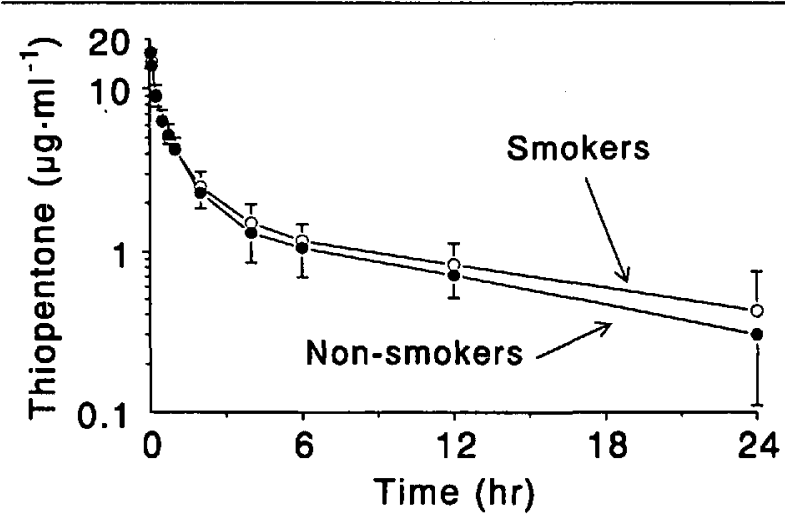

FIGURE 2 Concentrations (mean $\pm S D$ ) of thiopentone in plasma after an induction dose of $9 \mathrm{mg} \cdot \mathrm{kg}^{-1}$ lean body mass to 15 smokers and 15 non-smokers undergoing general surgery. 
TABLE III Pharmacokinetic data

\begin{tabular}{llllll}
\hline & $V_{c}\left(l \cdot \mathrm{kg}^{-1}\right)$ & $V_{s s}\left(l \cdot \mathrm{kg}^{-1}\right)$ & $C L\left(\mathrm{ml}^{\prime} \mathrm{min}^{-1} \cdot \mathrm{kg}^{-1}\right)$ & $T_{1 / 3,1}(\mathrm{~min})$ & $T_{1 /, 2}(\mathrm{br})$ \\
\hline Smokers & $0.40 \pm 0.09$ & $2.2 \pm 0.5$ & $2.9 \pm 1.1$ & $23.9 \pm 6.0$ & $12.5 \pm 6.3$ \\
Non-smokers & $0.43 \pm 0.10$ & $2.2 \pm 0.7$ & $3.3 \pm 1.0$ & $25.9 \pm 4.6$ & $10.7 \pm 3.1$ \\
\hline
\end{tabular}

(mean $\pm S D$ ); $V_{c}=$ volume of the central compartment, $V_{s s}=$ volume of distribution at steady state, $C L=$ clearance, $T_{1 /, 1}=$ "fast" half life and $T_{1,2}=$ "slow" half-life.

TABLE IV Haemodynamic data

\begin{tabular}{lllll}
\hline & & Preinduction & Preintubation & Postintubation \\
\hline SAP & S & $155 \pm 29$ & $127 \pm 24^{*}$ & $192 \pm 35^{+}$ \\
(mmHg) & NS & $153 \pm 21$ & $136 \pm 22^{*}$ & $189 \pm 20^{+}$ \\
HR & S & $77 \pm 13$ & $92 \pm 13^{*}$ & $103 \pm 12^{+}$ \\
(bpm) & NS & $82 \pm 19$ & $88 \pm 19$ & $102 \pm 17^{+}$ \\
\hline
\end{tabular}

$($ mean $\pm S D) ; S=$ smokers, NS = non-smokers; SAP = systolic arteri al pressure, $\mathrm{HR}=$ heart rate; Significance from preinduction values: $P<0.05^{*}$ within the groups. Significance from preintubation values: $P<0.05^{\dagger}$ within the groups.

variables between smokers and non-smokers did not differ (Table III).

The haemodynamic intubation response was similar in both groups (Table IV). The systolic arterial pressures (SAP) increased from pre-intubation values in smokers and in non-smokers, but there was no difference between the groups. Heart rate increased in both groups, with no difference between groups.

\section{Discussion}

Cigarette smoking had no effect on the pharmacodynamic behaviour of thiopentone as quantified by auditory evoked potentials. Also the pharmacokinetics of thiopentone, as well as haemodynamic variables were similar in smokers and in non-smokers.

Thiopentone pharmacodynamics were evaluated using auditory evoked potentials, which have been validated as a reliable monitor of the adequacy of anaesthesia. ${ }^{19}$ The middle latency auditory waves are thought to originate from the medial geniculate and primary auditory cortex. ${ }^{20}$ Increases in the latencies of $\mathrm{Pa}$ and $\mathrm{Nb}$ waveforms indicate deepening unconsciousness. ${ }^{19,21}$ The phenomenon is similar with most general anaesthetics. ${ }^{19}$ Amplitudes of MLAEP's, on the other hand, seem to reflect patients' reaction to surgical stimulation. The amplitudes of $\mathrm{Nb}$ and $\mathrm{Pb}$ waveforms increase after start of surgery. ${ }^{22}$ High dose fentanyl anaesthesia, providing excellent analgesia, blunts this response. ${ }^{23}$ Increases in latency and decreases in amplitude of MLAEPs have also been noted following thiopentone induction. ${ }^{19,24}$ In our study, too, the induction dose of thiopentone, $9 \mathrm{mg} \cdot \mathrm{kg}^{-1}$ LBM, caused a depression in cortical response as mea- sured by MLAEP, while tracheal intubation caused an increase in responsiveness. Schwender et al. have shown that thiopentone induction produces an increase in the latencies and decrease in amplitudes of MLAEP for up to four minutes. ${ }^{24}$ Those data correspond closely with ours up to two minutes after thiopentone administration. In our study the waves of MLAEP latencies decreased and amplitudes increased after tracheal intubation (three minutes after thiopentone administration) in both smokers and non-smokers, compared with pre-intubation values. This is, presumably, caused partly by the rapid change of the thiopentone concentration in the brain due to the drug redistribution and the lightening of anaesthesia produced by the stimulus of laryngoscopy and tracheal intubation.

After rapid intravenous administration of thiopentone the termination of its hypnotic effect is due to redistribution of the drug. Ultimately, thiopentone is eliminated hepatically. Derived parameters describing the distribution and elimination of thiopentone were similar in smokers and non-smokers. The values for $V_{\text {ss }}$ varied from 1.1 to $3.11 . \mathrm{kg}^{-1}$ and those of CL from 1.0 to $5.7 \mathrm{ml} \cdot \mathrm{min}^{-1} \cdot \mathrm{kg}^{-1}$. Both values were similar to those described previously. ${ }^{10}$

Several neurophysiological studics have shown depression in brain activity following the anaesthetic induction and an increase in brain activity after tracheal intubation. ${ }^{24-28}$ The serum thiopentone concentration $\left(\mathrm{Cp}_{50}\right)$ that blunts the moving response in $50 \%$ of unparalysed patients for laryngoscopy was shown to be $50.7 \mu \mathrm{g} \cdot \mathrm{ml}^{-1}$, while the $\mathrm{Cp}_{50}$ for laryngoscopy and tracheal intubation was $78.8 \mu \mathrm{g} \cdot \mathrm{ml}^{-1} .{ }^{25}$ In our study, the mean thiopentone concentration at the time of intubation was approximately $16 \mu \mathrm{g} \cdot \mathrm{ml}^{-1}$ both in smokers and in non-smokers. As the serum levels of thiopentone are not in equilibrium with brain after iv injection, relevant comparisons can hardly be performed. The haemodynamic responses to laryngoscopy and intubation were not blunted. The similar increase in SAP and heart rate in smokers and nonsmokers shows that the immediate pharmacodynamic effect of thiopentone is unaffected by smoking. The mean $\mathrm{Nb}$ wave latencies after tracheal intubation were above $48 \mathrm{msec}$, indicating unconsciousness. ${ }^{19}$ None of 
the patients had any memory or any signs of conscious post-induction awareness.

We used a large dose of thiopentone (approx. $\left.7 \mathrm{mg} \cdot \mathrm{kg}^{-1}\right)$. This dose was chosen after pilot testing to avoid extremely high postintubation arterial pressures in patients not receiving opioids. We also wanted to ensure unconsciousness in unpremedicated patients by increasing the dose of thiopentone. Recently, Flaishon et al. showed that some patients can recover consciousness very rapidly after thiopentone, possibly even before intubation. ${ }^{29}$ Due to our mode of administration of thiopentone, no recall occurred in our study. However, as the present data show, haemodynamic responses are poor measures of anaesthetic adequacy after thiopentone.

To our knowledge, this is the first study where auditory evoked potentials were used to measure the effect of smoking on thiopentone pharmacodynamics. In a study by Dundee et al., ${ }^{8}$ where the abolition of the eyelash reflex was measured, moderate or heavy drinking increased the induction dose requirements for thiopentone while the use of tobacco alone had no effect. Our results are in line with that report.

Intravenous anaesthetic induction causes rapid changes in the level of consciousness. Each evoked potential recording lasted about $60 \mathrm{sec}$. Thus, we could not measure anaesthetic "depth" in stable, stationary conditions. The patients may have been in lighter plane of anaesthesia at the end of the latest recording than the averaged waveform showed. We could have shortened the recording time by decreasing the number of averaged responses. However, we decided to average 500 responses to enhance the waveform reliability. The evoked responses of all patients were recorded in the same way, and nobody was awake during the study.

Smoking has been shown to increase the metabolism of many drugs. For instance, imipramine, theophylline and warfarin are metabolised faster in smokers than in non-smokers. ${ }^{1,2}$ These drugs are metabolised mainly by cytochrome $1 \mathrm{~A}$ and $2 \mathrm{C}$ subfamilies. ${ }^{30}$ The isoenzymes responsible for the metabolism of thiopentone are not known. Previous studies have shown that longer-acting barbiturates phenobarbitone and hexobarbitone are metabolised at least partly by cytochrome 2 family. ${ }^{31}$ However, whatever isoenzyme is mainly responsible for the metabolism of thiopentone, it does not appear to be affected by smoking. Cigarette smokers have greater upper airway reflex sensitivity and bronchial hyper-reactivity. ${ }^{6,7}$ They are more likely to demonstrate laryngospasm, cough and airway obstruction than are non-smokers. Similar signs are sometimes associated with light anaesthesia.
Our study, using objective measures of anaesthetic adequacy, suggests that the altered pharmacodynamic or pharmacokinetic behaviour of thiopentone does not explain the greater incidence of laryngospasm and other airway problems in smokers.

In conclusion, thiopentone, $9 \mathrm{mg} \cdot \mathrm{kg}^{-1} \mathrm{LBM}$, caused cortical and haemodynamic depression, while cortical activity and haemodynamic variables were increased after a standardised stimulus of laryngoscopy and tracheal intubation. These responses were not affected by cigarette smoking. Pharmacokinetic analysis of thiopentone showed no difference between smokers and nonsmokers. In this study cigarette smoking did not affect the pharmacodynamic or the pharmacokinetic behaviour of thiopentone.

\section{References}

1 Miller LG. Cigarettes and drug therapy: pharmacokinetic and pharmacodynamic considerations. Clinical Pharmacy 1990; 9: 125-35.

2 Miller LG. Recent developments in the study of the effects of cigarette smoking on clinical pharmacokinetics and clinical pharmacodynamics. Clin Pharmacokinet 1989; 17: 90-108.

3 Dawson GW, Vestal RE. Smoking and drug metabolism. Pharmacol Ther 1982; 15: 207-21.

4 Vähäkangas K, Pelkonen O, Sotaniemi E. Cigarette smoking and drug metabolism. Clin Pharmacol Ther 1983; 33: 375-80.

5 Ochs HR, Greenblatt DJ, Kniichel M. Kinetics of diazepam, midazolam, and lorazepam in cigarette smokers. Chest 1985; 87: 223-6.

6 Dennis A, Curran J, Sherriff J, Kinnear W. Effects of passive and active smoking on induction of anaesthesia. $\mathrm{Br}$ J Anaesth 1994; 73: 450-2.

7 Erskine RJ, Murphy PJ, Langton JA. Sensitivity of upper airway reflexes in cigarette smokers: effect of abstinence. Br J Anaesth 1994; 73: 298-302.

8 Dundee JW, Hassard TH, McGowan WAW, Henshaw J. The "induction" dose of thiopentone. A method of study and preliminary illustrative results. Anaesthesia 1982; 37: 1176-84.

9 Russo H, Brès J, Duboin M-P, Roguefeuil B. Variability of thiopental clearance in routine critical care patients. Eur J Clin Pharmacol 1995; 48: 479-87.

10 Hudson RJ, Stanski DR, Burch PG. Pharmacokinetics of methohexital and thiopental in surgical patients. Anesthesiology 1983; 59: 215-9.

11 Roizen MF. Anesthetic implications of concurrent diseases. In: Miller RD (Ed.). Anesthesia, 4th ed. New York: Churchill Livingstone Inc., 1994: 903-1014.

12 Schwilden $H$. Optimierung der dosierung volatiler anästhetika auf der grundlage pharmakokinetischdy- 
namischer modelle. Anästhesie Intensivtherapie Notfallmedizin 1985; 20: 307-15.

13 Freeman DJ. Monitoring serum thiopental concentrations by liquid chromatography. Clin Chem 1981; 27: 1942-3.

14 Wilkinson L. SYSTAT: The System for Statistics. Evanston: SYSTAT, Inc. 1990.

15 Yamaoka K, Nakagawa T, Uno T. Application of Akaike's information criterion (AIC) in the evaluation of linear pharmacokinetic equations. J Pharmacokin Biopharm 1978; 6: 165-75.

16 Dunne $A$. An iterative curve stripping technique for pharmacokinetic parameter estimation. J Pharm Pharmacol 1986; 38: 97-101.

17 Wagner JG. Linear Pharmacokinetic equations allowing direct calculation of many needed pharmacokinetic parameters from the coefficients and exponents of polyexponential equations which have been fitted to the data. J Pharmacokin Biopharm 1976; 4: 443-67.

18 Loo JCK, Riegelman S. Assessment of pharmacokintic constants from postinfusion blood curves obtained after I.V. infusion. J Pharm Sci 1970; 59: 53-5.

19 Thornton $C$. Evoked potentials in anaesthesia. Eur J Anaesthesiol 1991; 8: 89-107.

20 Woods DL, Clayworth CC, Knight RT, Simpson GV, Naeser $M A$. Generators of middle- and long-latency auditory evoked potentials: implications from studies of patients with bitemporal lesions. Electroencephalogr Clin Neurophysiol 1987; 68: 132-48.

21 Newton DEF, Thornton C, Konieczko KM, et al. Auditory evoked response and awareness: a study in volunteers at sub-MAC concentrations of isoflurane. Br J Anaesth 1992; 69: 122-9.

22 Thornton C, Konieczko K, Jones JG, Jordan C, Doré C), Heneghan CPH. Effect of surgical stimulation on the auditory evoked response. $\mathrm{Br}$ J Anaesth 1988; 60: $372-8$.

23 Schwender D, Golling W, Klasing $S$, Faber-Züllig $E$, Pöppel E, Peter K. Effects of surgical stimulation on midlatency auditory evoked potentials during general anaesthesia with propofol/fentanyl, isoflurane/fentanyl and flunitrazepam/fentanyl. Anaesthesia 1994; 49: 572-8.

24 Schwender D, Klasing S, Madler C, Pöppel E, Peter K. Midlatency auditory evoked potentials and purposeful movements after thiopentone bolus injection. Anaesthesia 1994; 49: 99-104.

25 Hung OR, Varvel JR, Shafer SL, Stanski DR. Thiopental pharmacodynamics. II. Quantitation of clinical and electroencephalographic depth of anesthesia. Anesthesiology 1992; 77: 237-44.

26 Kanaya N, Nakayama M, Fujita S, Namiki A. Haemodynamic and EEG changes during rapid- sequence induction of anaesthesia. Can J Anaesth 1994; 41: 699-702.

27 Wilder-Smith $O H G$, Hagon O, Tassonyi E. EEG arousal during laryngoscopy and intubation: comparison of thiopentone or propofol supplemented with nitrous oxide. Br J Anaesth 1995; 75: 441-6.

28 Richmond CE, Matson A, Thornton C, Doré CJ, Newton DEF. Effect of neuromuscular block on depth of anaesthesia as measured by the auditory evoked response. Br J Anaesth 1996; 76: 446-8.

29 Flaishon R, Windsor A, Sigl J, Sebel PS. Recovery of consciousness after thiopental or propofol. Anesthesiology 1997; 86:613-9.

30 Brockmöller J, Roots I. Assessment of liver metabolic function. Clinical implications. Clin Pharmacokinet 1994; 27: 216-48.

31 Cholerton $S, D a l y A K$, Idle $J R$. The role of individual human cytochromes $\mathrm{P} 450$ in drug metabolism and clinical response. Trends Pharmacol Sci 1992; 13: 434-9. 